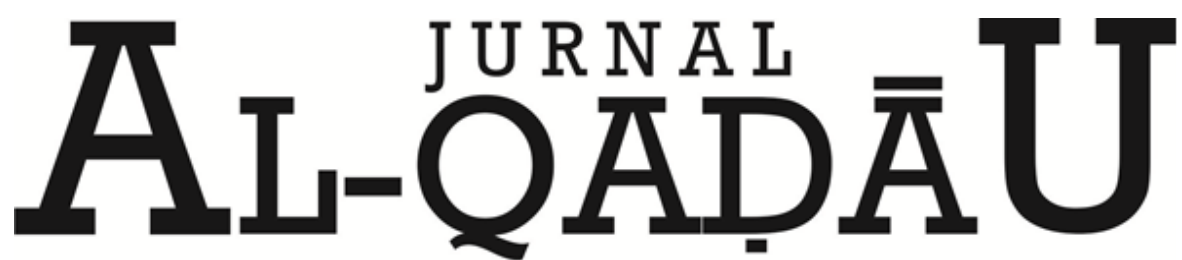 \\ PERADILAN dan HUKUM KELUARGA ISLAM
}

\section{Kesaksian Perempuan Perspektif Fikih}

The Testimony of Women in Fiqh Perspective

Nur Aisyah

Dosen Universitas Islam Negeri Alauddin Makassar

Email : aisyahuin@gmail.com

\begin{tabular}{|c|c|}
\hline $\begin{array}{c}\text { Info } \\
\text { Artikel }\end{array}$ & Abstract \\
\hline $\begin{array}{l}\text { Diterima } \\
23\end{array}$ & \\
\hline $\begin{array}{l}\text { Februari } \\
2017 \\
\text { Revisi I } \\
20 \\
\text { Maret } \\
2017\end{array}$ & $\begin{array}{l}\text { Saksi merupakan informasi yang diberikan oleh orang yang jujur untuk } \\
\text { membuktikan kebenaran dengan lafal kesaksian di dalam majelis } \\
\text { persidangan. Salah satu problem yang menjadi perdebatan adalah } \\
\text { tentang kesaksian perempuan. Mengenai kedudukan perempuan untuk } \\
\text { dapat menjadi saksi, pada dasarnya ulama fikih mengakuinya. Namun } \\
\text { demikian, ulama fikih berbeda pendapat tentang penerimaan kesaksian } \\
\text { perempuan baik berdasarkan jumlah saksi maupun masalah yang } \\
\text { dimintakan kesaksian. }\end{array}$ \\
\hline $\begin{array}{l}\text { Revisi II } \\
13 \\
\text { April } \\
2017\end{array}$ & Kata Kunci : Saksi, Perempuan \\
\hline $\begin{array}{l}\text { Disetujui } \\
23 \\
\text { Mei } \\
2017\end{array}$ & $\begin{array}{l}\text { Witness is the information provided by people who are honest to prove the } \\
\text { truth by pronunciations witness in the trial chamber. One of the problems } \\
\text { is a debate about the woman's testimony. Regarding the position of women } \\
\text { to be able to be witness, basically jurists admit it. However, jurists differ } \\
\text { on admission of testimony by women based on the number of witnesses } \\
\text { and issue the requested testimony. } \\
\text { Keywords : Witness, Women }\end{array}$ \\
\hline
\end{tabular}


Nur Aisyah

\section{PENDAHULUAN}

\section{A. Latar Belakang}

Di antara isu yang sering menjadi bahan perdebatan berkaitan dengan kedudukan perempuan didalam Hukum Islam, apakah setara dengan kaum laki-laki atau tidak, adalah kesaksian perempuan. Pemahaman yang tersebar luas selama ini di kalangan masyarakat muslim adalah bahwa nilai kesaksian perempuan separoh kesaksian laki-laki sebagaimana termuat dalam berbagai kitab fikih maupun tafsir. Pemahaman yang seperti itu tampaknya saat ini banyak menuai kritik, karena seolah-olah menempatkan posisi kaum perempuan lebih rendah dari pada kaum laki-laki. Akibatnya, banyak tudingan terhadap Islam sebagai agama yang diskriminatif terhadap kaum perempuan.

Pemahaman demikian menarik untuk dibahas karena secara tidak langsung hal itu sama dengan memposisikan laki-laki di atas perempuan atau dengan kata lain derajat perempuan berada di bawah laki-laki. Penafsiran tersebut bertolak belakang dengan prinsip Islam yang digali dari al-Quran dan hadis bahwa semua manusia setara di hadapan Allah baik laki-laki maupun perempuan. Pembedanya hanya tingkat ketakwaan.

Kalau ada perbedaan, itu hanyalah akibat dari fungsi dan tugas-tugas utama yang dibebankan oleh Islam kepada masing-masing jenis kelamin, sehingga perbedaan yang ada tidak mengakibatkan yang satu merasa bahwa ia memiliki kelebihan atas yang lain, mereka saling melengkapi dan saling menolong.

Memang ada ayat yang menegaskan bahwa "Para laki-laki (suami) adalah pemimpin para perempuan (istri) (QS. al-nisa (3): 4. Namun sebenarnya ayat ini hanyalah berupa anjuran bagi para suami untuk memperlakukan istrinya dengan sifat terpuji, agar mereka dapat memperoleh kehidupan ideal dalam keluarga. Bukan berarti ayat ini meyatakan bahwa laki-laki selalu berada di atas perempuan.

\section{B. Rumusan Masalah}

Berdasarkan latar belakang tersebut, maka dapat di tarik beberapa rumusan masalah, sebagai berikut:

1. Apa pengertian, dasar hukum dan syarat-syarat saksi ?

2. Bagaimana Pandangan ulama terhadap kesaksian perempuan? 


\section{PEMBAHASAN}

\section{A. Pengertian, Dasar Hukum dan Syarat-Syarat Saksi}

\section{Pengertian}

Menurut etimologi (bahasa) kata saksi dalam bahasa arab dikenal dengan Asy-syahadah ( الثهادة) adalah bentuk isim masdar dari kata يشهد شهر (syahida-yasyhadu) yang artinya menghadiri, menyaksikan (dengan mata kepala sendiri) dan mengetahui. ${ }^{1}$ sedangkan secara syar'i bermakna informasi yang diberikan oleh orang yang jujur untuk membuktikan kebenaran dengan lafal kesaksian di dalam majelis persidangan. ${ }^{2}$

\section{Dasar Hukum Saksi}

Adapun yang menjadi dasar hukum kesaksian diantaranya adalah :

Firman Allah swt, Q.S. al-Baqarah (2) : 282.

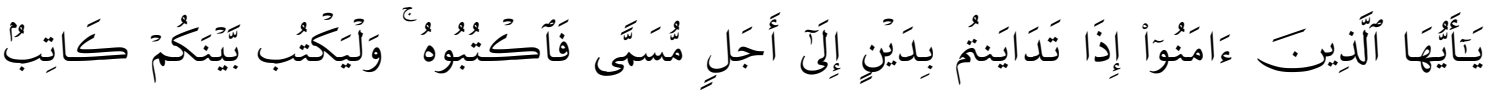

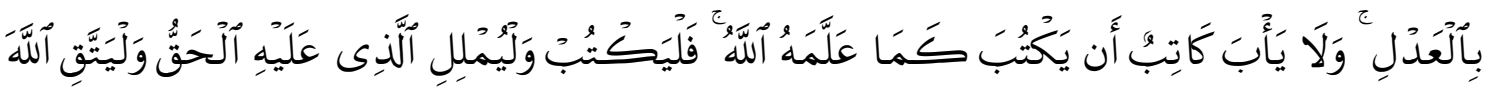

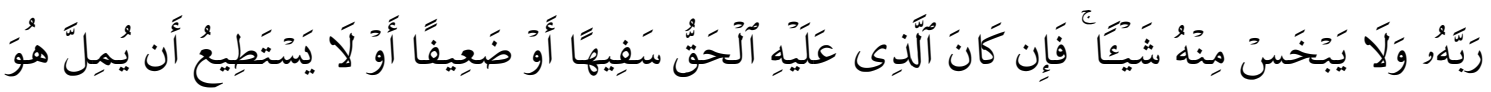

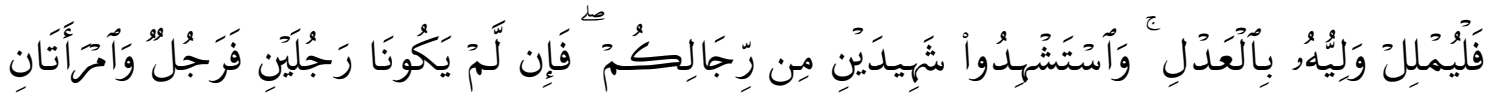

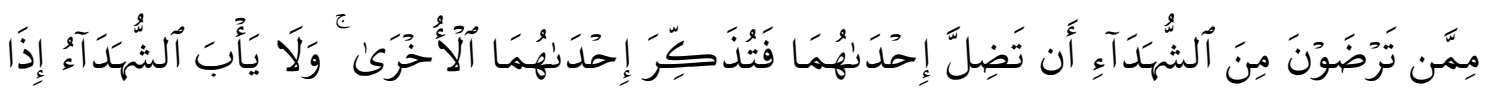

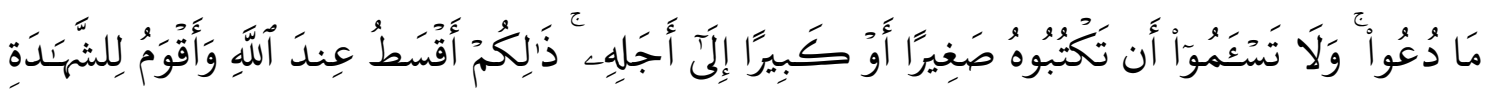

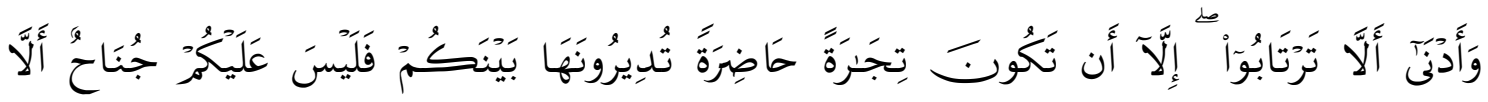

${ }^{1}$ A. Warson Moenawwir, Al-Munawir, Kamus Arab-Indonesia (Cet. 2; Surabaya: Pustaka Progresif, 2002), h. 746-747.

${ }^{2}$ Wahbah Az-Zuhayli, Al-Fiqh al-Islāmiy wa Adillatuhu (Cet. 3; Damaskus: Dār al-Fikr, 1409 H/1989 M), h. 556. 

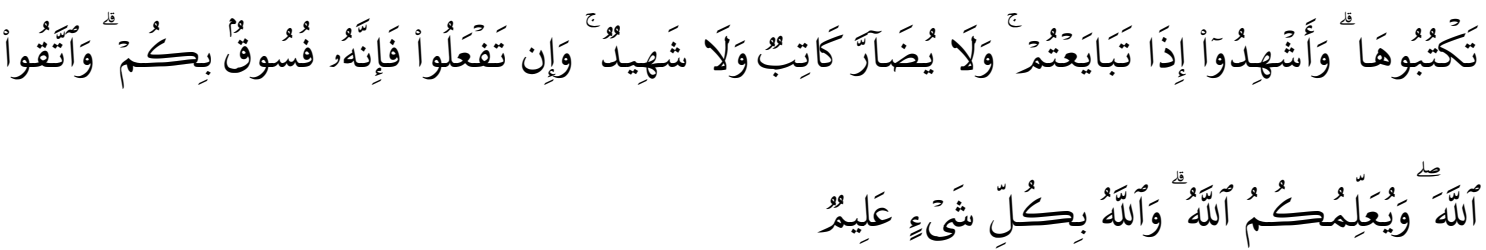

Terjemahnya:

Hai orang-orang yang beriman, apabila kamu bermu'amalah tidak secara tunai untuk waktu yang ditentukan, hendaklah kamu menuliskannya. dan hendaklah seorang penulis di antara kamu menuliskannya dengan benar. dan janganlah penulis enggan menuliskannya sebagaimana Allah mengajarkannya, meka hendaklah ia menulis, dan hendaklah orang yang berhutang itu mengimlakkan (apa yang akan ditulis itu), dan hendaklah ia bertakwa kepada Allah Tuhannya, dan janganlah ia mengurangi sedikitpun daripada hutangnya. jika yang berhutang itu orang yang lemah akalnya atau lemah (keadaannya) atau Dia sendiri tidak mampu mengimlakkan, Maka hendaklah walinya mengimlakkan dengan jujur. dan persaksikanlah dengan dua orang saksi dari orang-orang lelaki (di antaramu). jika tak ada dua oang lelaki, Maka (boleh) seorang lelaki dan dua orang perempuan dari saksi-saksi yang kamu ridhai, supaya jika seorang lupa Maka yang seorang mengingatkannya. janganlah saksi-saksi itu enggan (memberi keterangan) apabila mereka dipanggil; dan janganlah kamu jemu menulis hutang itu, baik kecil maupun besar sampai batas waktu membayarnya. yang demikian itu, lebih adil di sisi Allah dan lebih menguatkan persaksian dan lebih dekat kepada tidak (menimbulkan) keraguanmu. (Tulislah mu'amalahmu itu), kecuali jika mu'amalah itu perdagangan tunai yang kamu jalankan di antara kamu, Maka tidak ada dosa bagi kamu, (jika) kamu tidak menulisnya. dan persaksikanlah apabila kamu berjual beli; dan janganlah penulis dan saksi saling sulit menyulitkan. jika kamu lakukan (yang demikian), Maka Sesungguhnya hal itu adalah suatu kefasikan pada dirimu. dan bertakwalah kepada Allah; Allah mengajarmu; dan Allah Maha mengetahui segala sesuatu. $^{3}$

Q.S. al-Thalaq (65): 2.

3 Departemen Agama RI, al - Qur'an dan Terjemahnya (Semarang: PT. Karya Toha Putra, 2002), h. 59-60. 


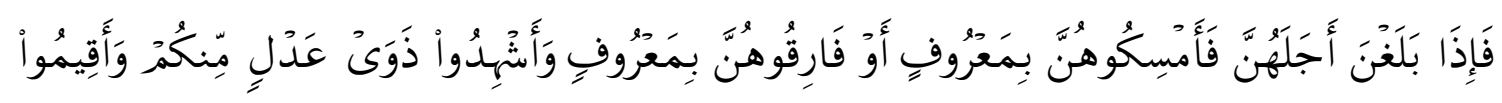

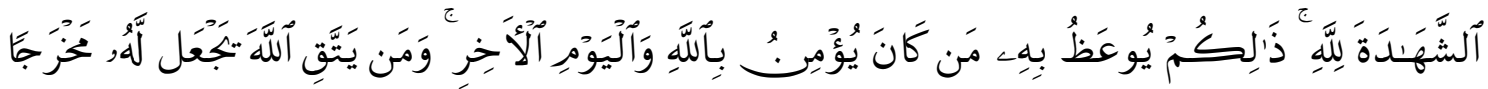

Terjemahnya: Apabila mereka telah mendekati akhir iddahnya, Maka rujukilah mereka dengan baik atau lepaskanlah mereka dengan baik dan persaksikanlah dengan dua orang saksi yang adil di antara kamu dan hendaklah kamu tegakkan kesaksian itu karena Allah. Demikianlah diberi pengajaran dengan itu orang yang beriman kepada Allah dan hari akhirat. Barangsiapa bertakwa kepada Allah niscaya Dia akan Mengadakan baginya jalan keluar. ${ }^{4}$

Adapun dalam hadis,

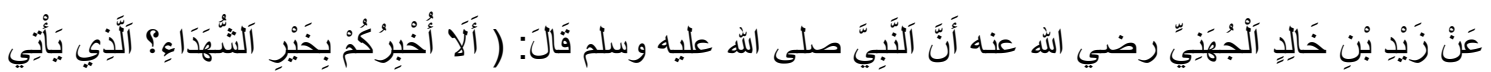

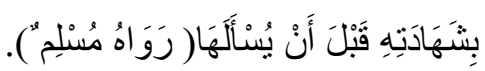

Artinya: Dari Zaid Ibnu Kholid al-Juhany bahwa Nabi Shallallaahu 'alaihi wa Sallam bersabda: "Maukah kalian aku beritahu sebaik-baik persaksian? Yaitu orang yang datang memberi saksi sebelum diminta persaksiannya." (Riwayat Muslim). ${ }^{5}$

\section{Syarat-Syarat Saksi}

Syarat-syarat saksi secara umum menurut ulama fikih mencakup:

1. Berakal sehat dan baligh (dewasa)

Seorang saksi disyaratkan memenuhi kualifikasi berakal sehat dan balighberdasarkan kesepakatan fuqaha, sehingga kesaksian orang yang tidak berakal sehat tidak dapat diterima secara ijma', seperti orang gila, orang mabuk, dan anakkecil yang belum dewasa karena tidak dapat diperoleh kepercayaan melalui perkataan mereka.

Merdeka

${ }^{4}$ Departemen Agama RI, al-Qur'an dan Terjemahnya, h. 816.

5 al-Imam Muslim, Shahih Muslim, terj. Ma'mur Daud, Terjemah Hadis Shahih Muslim, Jilid II (Jakarta: Klang Book Centre, 1982), h. 60. 
Nur Aisyah

Ulama Hanafi, Maliki, dan Syafi'i sepakat bahwa saksi harus orang yang merdeka sehingga kesaksian budak tidak diterima. Namun demikian, pengertian merdeka dalam hal ini pada hakikatnya adalah tidak ada ancaman atau pun tekanan terhadap saksi.

Islam

Fuqaha sepakat bahwa saksi harus beragama Islam, sehingga tidak diterima kesaksian seorang kafir terhadap orang Islam. Akan tetapi, ulama Hanafi dan Hanbali membolehkan kesaksian seorang kafir dalam masalah wasiat yang dibuat dalam perjalanan.

Dalam praktek hukum acara yang berlaku di lingkungan Peradilan Agama, keabsahan saksi non-muslim dipertimbangkan berdasarkan kedudukan saksi tersebut, apakah sebagai syarat hukum atau sebagai alat pembuktian. Dalam hal saksi sebagai alat pembuktian, yang diperlukan dalam proses pemeriksaan di pengadilan untuk memperjelas suatu peristiwa dan kejadian yang dipersengketakan oleh para pihak yang berperkara, dan bukan masalah yang berhubungan dengan agama seperti dua orang saksi beragama Islam adalah syarat hukum untuk syahnya perkawinan, maka kesaksian non-muslim dapat diterima. ${ }^{6}$

2. Tidak buta

3. Tidak bisu

4. Adil

5. Netral (tidak ada kepentingan)

\section{B. Pandangan Ulama Terhadap Kesaksian Perempuan}

Pada dasarnya ulama fikih mengakui kedudukan perempuan untuk dapat menjadi saksi. Namun demikian, ulama fikih berbeda pendapat tentang penerimaan kesaksian perempuan baik berdasarkan jumlah saksi maupun masalah yang dimintakan kesaksian. $^{7}$

${ }^{6}$ Abdul Manan, Penerapan Hukum Acara Perdata di Lingkungan Peradilan Agama, Cet. 4 (Jakarta: Kencana, 2006), h. 381. Raihan A. Rasyid, Hukum Acara Peradilan Agama, Edisi Baru (Jakarta: PT. Raja Grafindo Persada, 2006), h. 160.

${ }^{7}$ Abdul Manan, Penerapan Hukum Acara Perdata di Lingkungan Peradilan Agama, h. 381. 
Adapun dalam masalah apa kesaksian dua orang perempuan tersebut dapat diterima bersama dengan kesaksian seorang laki-laki ulama fikih berbeda pendapat.

Menurut ulama Hanafi, kesaksian dua orang perempuan dan satu orang laki-laki dapat diterima dalam masalah yang berkaitan dengan hak-hak sipil, baik berupa harta maupun hak, atau yang tidak terkait dengan harta seperti nikah, talak, 'iddah, hiwālah, wakaf, wasiat, hibah, ikrar, ibra', kelahiran, nasab. Adapun penerimaan kesaksian perempuan tersebut didasarkan pada kualifikasi yang dimiliki oleh perempuan tersebut untuk menjadi saksi, yaitu perempuan tersebut memiliki kesaksian atas apa yang dilihat dan/atau didengar, kecermatan/ingatan yang kuat, dan kemampuan untuk memberikan kesaksian. Sementara nilai kesaksian dua orang perempuan sama dengan nilai kesaksian seorang laki-laki adalah karena perempuan lemah ingatannya karena lebih sering lupa.

Sedangkan menurut ulama Syafi'i, Maliki, dan Hanbali, kesaksian perempuan bersama laki-laki hanya dapat diterima dalam masalah harta dan yang terkait dengan harta seperti jual beli, sewa, hibah, wasiat, gadai, dan kafālah. ${ }^{8}$ Adapun sebab tidak diterimanya kesaksian perempuan adalah karena perempuan cenderung merasa belas kasihan, ingatan yang tidak utuh, dan keterbatasan kewenangan dalam berbagai hal.

Sementara dalam masalah yang tidak memiliki keterkaitan dengan harta dan tidak dimaksudkan untuk mendapatkan harta dan biasanya menjadi urusan kaum lakilaki seperti nikah, rujuk, talak, wakalah, pembunuhan dengan sengaja, dan hudud kecuali had zina hanya dapat ditetapkan berdasarkan kesaksian dua orang laki-laki.

Menurut jumhur ulama, dalam tindak pidana yang hukumnya kisas, saksi haruslah dua orang laki-laki, tidak diterima kesaksian satu orang laki-laki bersama dua orang perempuan. Berdasarkan hadis riwayat al-Nasa'i

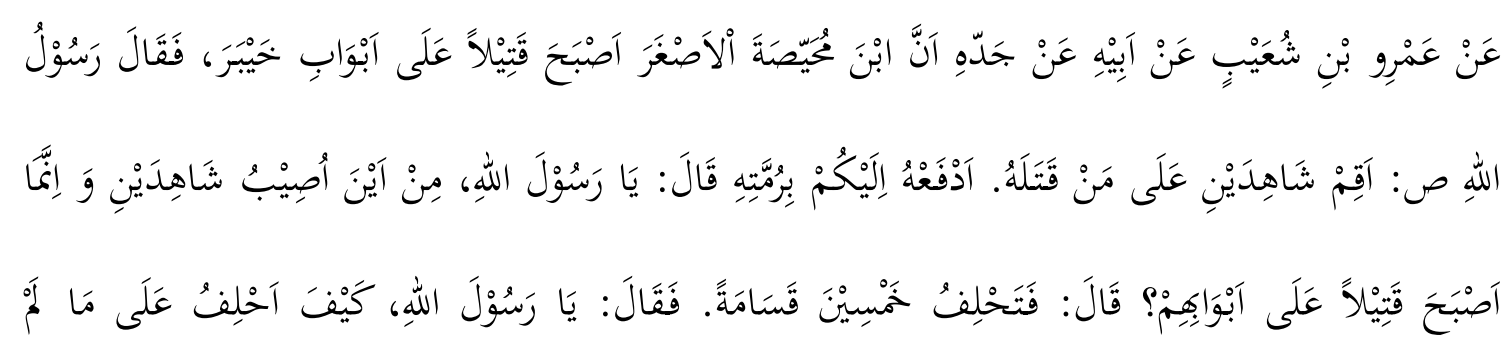

${ }^{8}$ al-'Allamah Muhammad bin Abdurrahman al-Dimasyqi, Rahmah al-Ummah fi Ikhtiläf alA'immah, terj. Abdullah Zaki al-Kaf, Fikhi Empat Mazhab (Cet. 2; Bandung: Hasyimi, 2004), h. 528. 
Artinya :

“ Dari 'Amr bin Syu'aib dari ayahnya dari kakeknya, bahwa sesungguhnya anak laki-laki Muhayyishash yang paling kecil terbunuh di gerbang Khaibar. Kemudian Rasulullah saw. bersabda, "Bawalah dua orang saksi atas orang yang membunuhnya, maka akan kuserahkan kepadamu dengan tali yang mengikatnya". Lalu mereka berkata, "Ya Rasulullah, dari mana aku dapat memperoleh dua orang saksi, sedang ia terbunuh di gerbang mereka (kaum Yahudi) ?”. Nabi saw. bersabda, "Kalau begitu kamu dapat mengumpulkan lima puluh orang untuk bersumpah". Lalu ia berkata, "Ya Rasulullah, bagaimana aku bisa bersumpah atas sesuatu yang aku sendiri tidak tahu ?”. Lalu Rasulullah saw. bersabda, "Kalau begitu mintalah lima puluh orang diantara mereka supaya bersumpah". Ia bertanya (lagi), "Ya Rasulullah, bagaimana mungkin kami menyumpah mereka, sedang mereka orang-orang Yahudi ?”. Kemudian Rasulullah saw. membagi diyatnya itu yang (separuh)-nya dibebankan kepada mereka (orang-orang Yahudi) dan beliau membantu yang separuhnya". (HR. Nasai)

al-Auzai dan al-Zuhri serta Imam al-Syaukani berpendapat, kesaksian perempuan dan dua orang laki-laki dapat diterima dalam tindak pidana yang hukumanya kisas. ${ }^{9}$

Menurut al-Syaukani, hadis di atas hanya menyatakan dua orang saksi laki-laki dalam kisas, bukan menunjukkan tidak diterimanya kesaksian satu orang laki-laki dan dua orang perempuan. Nabi hanya menuntut yang asal tidak boleh dengan selainnya, tetapi kalau tidak ada, maka boleh perempuan menjadi saksi dalam kisas, ${ }^{10}$ sebagaimana firman Allah dalam surah al-baqarah ayat 282.

Jadi, menurut al-Syaukani, kesaksian perempuan dalam penetapan hukuman kisas dapat diterima dengan syarat jumlahnya dua orang dan disertai laki-laki. Ibn

${ }^{9}$ al-Syaukani, Nailul al-'Authar(Jilid. VIII; Beirut: Dar al-Jill, t.t.),h. 181-182.

${ }^{10}$ Huzaimah Tahido Yanggo, Fikhi Perempuan Kontemporer (Cet. 1; Jakarta: Ghalia Indonesia, 2010), h. 162. 
Hazm membolehkan kesaksian perempuan dalam perkara kisas berdasarkan firman Allah dalam Q.S. al-Baqarah ayat 282.

Menurut al-Ghazali, pada pembunuhan tidak sengaja (Qatl al-Khata) dan semua pelukaan (al-Jarh) yang tidak mewajibkan diat selain harta saksinya, boleh terdiri atas satu orang laki-laki dan dua perempuan. hal ini karena ia memasukkan masalah tersebut dalam masalah yang berhubungan dengan harta. Imam Syafi'I hanya membolehkan kesaksian perempuan dalam pelukaan (al-jarh) yang tidak ada hukuman kisasnya, baik yang dilakukan dengan sengaja maupun tidak. Akan tetapi syaratnya haruslah disertai laki-laki.

Jadi, mayoritas fukaha sepakat bahwa dalam tindak pidana pembunuhan, khususnya yang hukuman kisas, syarat saksi haruslah laki-laki, olehnya kesaksian perempuan dalam masalah ini tidak diterima karena kesaksian perempuan mengandung unsur syubhat, berupa badal (keraguan dalam pergantian). Namun demikian, para ulama juga menerima kesaksian perempuan dalam masalah pembunuhan jika terdapat bukti-bukti yang jelas dan nyata untuk menetapkan kebenaran itu, sedangkan hakim bisa mempercayainya. ${ }^{11}$

Adapun dalam masalah had zina ulama bersepakat bahwa masalah tersebut hanya dapat ditetapkan minimal dengan kesaksian empat orang laki-laki yang merdeka, adil, dan beragama Islam.

Mengenai kesaksian dua orang perempuan mempunyai nilai kekuatan yang sama dengan seorang laki-laki, itu bukan karena perempuan memiliki akal yang lemah dan kekurang sempurnaan kemanusiaannya, yang karena itu menjadikan kesaksiannya berkurang kekuatannya tetapi hal itu disebabkan karena perempuan seperti dikatakan oleh Muhammad Abduh,"Tidak semestinya perempuan menyibukkan diri dengan berbagai urusan yang menyangkut masalah keuangan dan harta kekayaan lainnya karena daya ingat perempuan dalam urusan-urusan seperti ini cenderung lemah, tidak demikian halnnya dalam urusan-urusan kerumahtanggaan yang memang sudah menjadi

\footnotetext{
${ }^{11}$ Huzaimah Tahido Yanggo, Fikhi Perempuan Kontemporer, h. 162.
} 
Nur Aisyah

kesibukannya, dalam masalah ini daya ingat perempuan lebih kuat dari daya ingat lakilaki. $^{12}$

Selanjutnya menurut Mahmud Syaltut, ayat tersebut (Q.S. al-Baqarah (2): 282) turun berkenaan dengan kondisi yang lazim berlaku pada diri perempuan dan masih senantiasa bersifat demikianlah sebagian perempuan, mereka tidak menghadiri majelismajelis utang piutang dan bursa-bursa perdagangan. Akan lain halnya jika sebagian mereka ada yang giat beraktifitas dalam bidang ini, maka hal itu sama sekali tidak meniadakan sifat-sifat yang memang sudah menjadi tabiat perempuan dalam hidupnya. Apabila ayat tadi memberi bimbingan kepada bentuk jaminan yang paripurna, sedang kaum perempuan juga diakui kehadiran dan keterlibatnnya dalam urusan perniagaan dan masalah utang-piutang yang ada dalam masyarakat, maka perempuan juga berhak dan memiliki nilai jaminan atau kekuatan hukum seperti halnya laki-laki. ${ }^{13}$

Menurut Imam al-Ghazali, pada kesaksian atas harta, hak-hak harta dan sebabnya kesaksian boleh terdiri atas seorang laki-laki dan dua orang perempuan dengan dalil Q.S. al-Baqarah (2): 282. Termasuk juga dalam kategori ini adalah syirkah (kerja sama), ijarah (sewa menyewa), itlaaf al-amwaal (merusak harta), 'uqud aldhaman (transaksi jaminan), pembunuhan keliru, setiap pelukaan yang tidak mewajibkan kecuali harta, hak khiyar (hak memilih), dan fasakh uqud (membatalkan transaksi). Menurut al-Kasani, ijma' tidak melarang kesaksian perempuan dalam masalah harta. ${ }^{14}$

Sementara dalam masalah yang tidak diketahui kecuali oleh kaum perempuan, kesaksian kaum perempuan saja dapat diterima tanpa harus bersama kesaksian kaum laki-laki. Namun mengenai batas-batas masalah yang dimaksud ulama berbeda pendapat. Menurut ulama Hanafi, kesaksian kaum perempuan saja dapat diterima dalam masalah kelahiran, keperawanan, dan cacat yang dimiliki kaum perempuan, tetapi dalam masalah penyusuan, dan tangis bayi pada saat kelahiran dalam hubungannya untuk mendapat warisan, kesaksian kaum perempuan saja tidak diterima.

\footnotetext{
${ }^{12}$ Huzaimah Tahido Yanggo, Fikhi Perempuan Kontemporer, h. 249.

${ }^{13}$ Mahmud Syaltut, Islam Aqidah dan Syari'ah, Jilid II (Cet. 1; Jakarta: Pustaka Amani Press, 1986), h. 249.

${ }^{14}$ Huzaimah Tahido Yanggo, Fikhi Perempuan Kontemporer, h. 158.
} 
Sedangkan menurut ulama Maliki, Syafi'i, dan Hanbali, kesaksian perempuan saja dapat diterima dalam masalah yang tidak diketahui oleh kaum laki-laki secara umum seperti keperawanan, kegadisan, kelahiran, haid, penyusuan, tangis bayi pada saat kelahiran, dan cacat yang dimiliki kaum perempuan dibalik pakaian.

Dalam hal kesaksian kaum perempuan saja, ulama berbeda pendapat mengenai jumlah saksi perempuan tersebut. Ulama Hanafi dan Hanbali berpendapat kesaksian seorang perempuan saja yang adil dapat diterima.

Sementara ulama Maliki mensyaratkan dua orang saksi perempuan. Sedangkan ulama Syafi'i berpendapat minimal empat orang saksi perempuan.

\section{PENUTUP}

\section{A. Kesimpulan}

Pada dasarnya ulama fikih mengakui kedudukan perempuan untuk dapat menjadi saksi. Dalam perkara-perkara tertentu kesaksian perempuan dapat diterima dalam hal yang terkait dengan harta serta yang berkaitan dengan masalah yang tidak bisa diketahui kecuali kaum perempuan itu sendiri. kecuali kasus pernikahan, kisas, hudud, dan had zina kesaksian perempuan tidak dapat diterima.

\section{B. Saran}

Memperbandingkan kondisi perempuan sekarang di mana banyak perempuan menjadi pemimpin publik, bahkan menjadi presiden, menjadi komisaris utama sebuah perusahaan besar, akuntan terkemuka, penghafal Alquran, dan lain-lain sebagai jawaban dari tuduhan ulama zaman dahulu bahwa perempuan daya ingatnya lemah, pelupa, tidak bisa memimpin, akal dan agamanya kurang, maka tentu saja pandangan bahwa kesaksian perempuan separuh dari laki-laki harus dikaji lebih lanjut. Kenyataan sekarang perempuan telah setara dengan laki-laki hampir dalam segala bidang, karena perempuan juga telah memiliki akses yang hampir sama dengan laki-laki. Mengikuti perkembangan ini, maka perempuan sepatutnya disetarakan dengan laki-laki di hadapan hukum, termasuk dalam posisinya sebagai saksi dalam semua urusan, baik muamalat, munakahat, maupun jinayat khusus dibidang hudud dan qisas. 


\section{DAFTAR PUSTAKA}

Abdurrahman al-Dimasyqi, al-'Allamah Muhammad. Rahmah al-Ummah fi Ikhtilaf alA'immah, terj. Abdullah Zaki al-Kaf, Fikhi Empat Mazhab. Cet. 2; Bandung: Hasyimi, 2004.

al-Syaukani, Nailul al-'Authar. Jilid. VIII; Beirut: Dar al-Jill, t.t.

al-Zuhayli, Wahbah. Al-Fiqh al-Islāmiy wa Adillatuhu. Cet. 3; Damaskus: Dār al-Fikr, 1409 H/1989 M.

Manan, Abdul. Penerapan Hukum Acara Perdata di Lingkungan Peradilan Agama. Cet. 4; Jakarta: Kencana, 2006.

Moenawwir, A. Warson. Al-Munawir, Kamus Arab-Indonesia. Cet. 2; Surabaya: Pustaka Progresif, 2002.

Muslim ,al-Imam. Shahih Muslim, terj. Ma'mur Daud, Terjemah Hadis Shahih Muslim, Jilid II. Jakarta: Klang Book Centre, 1982.

Rasyid, Raihan A. Hukum Acara Peradilan Agama, Edisi Baru, Jakarta: PT. Raja Grafindo Persada, 2006.

RI, Departemen Agama. al - Qur'an dan Terjemahnya. Semarang: PT. Karya Toha Putra, 2002.

Syaltut, Mahmud. Islam Aqidah dan Syari'ah, Jilid II, Cet. 1; Jakarta: Pustaka Amani Press, 1986.

Yanggo, Huzaimah Tahido. Fikhi Perempuan Kontemporer. Cet. 1; Jakarta: Ghalia Indonesia, 2010. 